\title{
THE IMPACT OF THE GLOBAL COVID-19 PANDEMIC ON THE SELECTED PRACTICES OF HUMAN RESOURCES MANAGEMENT IN THE RELATIONSHIP TO THE PERFORMANCE OF TOURISM COMPANIES
}

\author{
Luba TOMČÍKOVÁ* \\ University of Presov in Presov, Faculty of Management, Department of Management, Presov, Slovakia, e-mail: luba.tomcikova@unipo.sk \\ Nella SVETOZAROVOVÁ \\ University of Presov in Presov, Faculty of Management, Department of Management, Presov, Slovakia, e-mail: nella.svetozarovova@unipo.sk \\ Jana COCULOVÁ \\ University of Presov in Presov, Faculty of Management, Department of Management, Presov, Slovakia, e-mail: jana.coculova@unipo.sk
}

\section{Zuzana DAŇKOVÁ}

University of Presov in Presov, Faculty of Management,

Department of Intercultural Communication, Presov, Slovakia, e-mail: zuzana.dankova@unipo.sk

\begin{abstract}
Citation: Tomčíková, L., Svetozarovová, N., Cocul'ová, J., \& Daňková, Z. (2021). THE IMPACT OF THE GLOBAL COVID-19 PANDEMIC ON THE SELECTED PRACTICES OF HUMAN RESOURCES MANAGEMENT IN THE RELATIONSHIP TO THE PERFORMANCE OF TOURISM COMPANIES. GeoJournal of Tourism and Geosites, 35(2), 525-530. https://doi.org/10.30892/gtg.35233-680
\end{abstract}

\begin{abstract}
This article focuses on human resources management in relationship to organizational performance in global Covid-19 pandemic times, particularly in the tourism companies operating in the Slovak Republic. From the theoretical part, the paper focuses on the evaluation of the situation in hospitality caused by Covid-19 in tourism companies in the current business environment and look at the more detailed human resources management, as many scholars point to some irregularities. The paper also presents the research results that was carried out on 274 respondents of managers who work in hospitality and the other sectors in this field. For research purposes, we suggested and tested the research hypothesis to analyze the statistically significant relationship between the impact of Covid-19 on the selected human resource management practices and the performance development of tourism companies in the Slovak Republic. There were the following practices: recruitment and selection of employees, education (training) and development, evaluation and management of employees' performance, rewarding and employee participation. The hypothesis was verified by correlation analysis with the use of inductive statistic. The hypothesis was verified at the end. The article points at the fact, that the procedures and practices of human resources are affected by Covid-19, as the other sector of human resources management. Also, the impact of Covid-19 affects the changes in the performance development of tourism companies operating in the Slovakia.
\end{abstract}

Key words: tourism, organizational performance, global Covid-19 pandemic, practices and procedures of human resources management in tourism services.

$* * * * * *$

\section{INTRODUCTION}

The economic, political and finally technological environment has changed in recent years significantly both on a national and international scale. The most significant challenges affecting current developments include the economic surroundings, explicitly, globalization, knowledge economy, demographic changes and the last pandemic Covid-19 crisis. These influences have their impacts on the area of human resources management in tourism companies, and of all other resources stepping into the reproduction process and can be easily imitated, but only human resources can create a very incomparable competitive advantage. The organizations at the beginning of the 21 st centuries have found themself in global competitiveness. The transformation from industrial to knowledge organization and the growing tasks of human capital have put the organization to face the new challenges of finding procedures to stay competitive. The changes in demographic, globalization, and as well as lack of a highly qualified workforce, in particular, have a significant effect on the organization ability of individ ual countries to sustain their stability. At the early beginning of the year 2020, all companies areas face up global pandemic issue caused by a new virus. The most affected among all companies are those related to tourism. In fact of dramatic changes regarding covid-19, the companies must react and adapt to the changes and manage human resources responsibly. All these changes require organizations to identify and implement new recruitment and development strategies. The employees must acquire a variety of skills that enable them to cope with new technologies and functions in companies affected by global pandemic effects. The technological progress, deployment of informative communicative technologies and growing radical globalization create a new business environment. These changes are affecting both the workforce and the methods of how human resources are managed. Gallo et al. (2019) state, that business companies must respond to ever- 
changing market situation and be able to adapt to these changes professionally. In this context, companies need to employ appropriate managers with innovative approaches bringing new business ideas and trends. The companies that want to remain competitive and efficient today still need to respond adequately to human resource management practices in line with these technological and structural changes (Moyo, 2020; Donthu and Gustafsson, 2020; Carnevale and Hatak, 2020) state, that the pandemic has affected the operation of businesses and the management of human resources.

\section{LITERATURE REVIEW}

\section{The global pandemic Covid-19 and tourism sector in current}

In the current turbulent times, it is inevitable for human resources to face many challenges, so the most significant assets, so-called human resources, should remain vital to fulfil the function of idiosyncratic competitive advantage. The pandemic Covid-19 presents the major challenge for the managers of all tourism companies operating in various field to consider the implementation of new managerial methods and tools in this unstable and changeable world. The pandemic Covid-19 presents the major challenge for the managers of all tourism companies operating in various field to consider the implementation of new managerial methods and tools in this unstable and changeable world. Remotely work, creating virtual teams, knowledge management is some of the many practices that most companies adopt as a concept to keep the companies run smoothly (Carnevale and Hatak, 2020). Most managers try to help their workforce adapt to the current pandemic situation and subsequently cope with the radical changes that take place in the work and social environment (Baert et al., 2020). BelzuneguiEraso and Erro-Garcés (2020) suggest that one of the main challenges in the field of human resources management, caused by pandemic Covid-19, are difficulties to adapt new and current employee as well as to copy very radical changes in working conditions which include both transportation to working place in a remote location and the implementation of new undesirable working conditions, policies and procedures in the workplace. Based on literature analyses, we can state that among the main challenges that need to be addressed for a long time, we can include the globalization process, transformation to the knowled ge economy, talent management, diversity management, conversation of human resources practices, demographic development, strategic human resources management, manager's professionalism in human resources management and as well the changes in activities of human resources departments. It is therefore inevitable to face such challenges and react to their impact during a pandemic. Varma et al. (2008) state that currently international companies have to dominate position when doing business because their advantage is the ability to do business in a wide range of business environment. In addition, they employ worldwide workforces and face importance due to the transition of systems in human resources management.

What does it mean for companies operating in tourism during the current business environment? These companies are nowadays in the middle of turbulent and complicated business environment. Over the decades, tourism has become one of the most progressive and most developed economic sector based on the growth and deepening diversification. Modern tourism included a growing number of new destinations and was closely linked to development, as a result of which tourism has become a key factor in socio-economic progress. It was significant and valid only for the period that was not affected by pandemic Covid19. The global expansion of tourism in the industrialized, developed countries have increased pre-pandemic economic advantages for employment in many sectors and contributed to economic prosperity (UNWTO, 2018). Tourism in many countries is considered the dominant pillar of the economy and its significant source of employment. However, regarding the outbreak of Covid-19, there is a high level of unemployment in this business area. World Travel and Tourism Council (WTTC, 2019) refered the importance of the tourism sector and hospitality and the importance of employment in this industry for industrialized and developed countries. In 2018, the industry sector represented $10.4 \%$ of world GDP and activities related to travel and tourism for 319 billion workplaces equal to $10 \%$ of the worldwide workplace (WTTC, 2019). Nowadays, however, the sector of tourism and hospitality is particularly vulnerable in such uncertain economic cycles. Based on the literature it is said that common crisis reasons are unforeseen events. Laws et al. (2006) define a tourism crisis as an exceptional event associated with increasing media attention, economic losses, accidents/injuries or deaths. These are unfavourable events that caused stable situations into the crises (Glaesser, 2006). They can often occur without warnings and with effects that are serious and disastrous for the government and the business communities. There are inevitable episodic events that continuously disturb the industry and cause shock for tourism companies (Pforr and Hosie, 2008). According to Bakri et al., 2014; Matijová et al., 2019, the tourism sector has an ability to generate and increase income, employment, and raise the living standards. Therefore, the investment in tourism development should be of interest to the governments as it helps ensuring the economic benefits.

\section{Human resources management (HRM) in tourism companies}

Tourism is an essential part of modern society, a dynamically evolving phenomenon that affects the economic and social sphere of most countries around the world (Királ'ová and Malec, 2016). To look at human resources management in tourism, many authors point to irregularities. Baum (2007, 2015), Nickson (2007) and Saad (2013) found irrational approaches in the field of human resources practices in companies related to tourism and hospitality, such as the fact that companies have an interest in providing excellent services, but yet most employees are either partially or not enough qualified. Instead of adequate training for the employees, managers do not take steps to improve this situation caused by high turnover in the industry. Another not very clear fact is that managers tend to employ low qualified workers to solve current issues like low productivity or turnover, instead of permanent positive impacts of human resources management (Saad, 2013).

The profitability and competitiveness of tourism companies should be one of the main goals of its management. In order to meet these goals, it is necessary to accomplish a particular performance and employees engagement, which are the main pillars of each company. The performance has a direct impact on the achievement of the organizational goals, but the performance is affected by the employees' skills, their motivation and other factors. We can state that performance is a particular and required 
set of skills, abilities and characteristics that an employee uses to fulfil his working tasks. A similar definition affirmed by several authors Wagner (2009), Wagnerová (2008). The performance reported by Turiecková (2004) is characterized as the essential criteria for organizational success. It is the so-called performance precondition. It results from the set of values, values from all society and individuals who are their part (Wagner, 2009). Many human resource management studies suggest that HRM has a positive impact on an organization's performance. According to Becker and Huselid (1998), there is remarkable evidence of the relationship between human resources management practices and organizational performance. Jiang et al. (2012) state that these practices and procedures in human resources related to financial results, which both, directly and indirectly, influence the human capital and employees motivation (Andresen and Nowak, 2015). The employee's performance as a result of their behaviour, such as engagement, quality and flexibility on which the many procedures have an enormous impact in human resources management: such as recruitment, training and development of employees, evaluation and rewarding of employees (Andresen and Nowak, 2015) which are significant to examine for our research in the relationship to performance development in tourism companies in the Slovak Republic during pandemic Covid-19.

\section{MATERIALS AND METHODS}

This article aims to research and to analyze the relationship between the impact of the covid-19 pandemic on the selected practices of human resources management and performance measures of tourism companies in the Slovak Republic, in these uncertain and turbulent times. The Covid-19 is considered the most urgent and actual topic with its impact on all business sectors, not only in Slovakia but in the world. In the tourism sectors and many others, the effect of human resources management and its way of managing changes rapidly. Companies are increasingly using the digital tools to identify, recruit and retain employees by online or telephone recruitment, and the adaptation of employees as many others are common to use. The survey in Estonia (Vösa, 2010) points to the recruitment of employees during the crisis that is a significant challenge regarding the organization's incapability to employ a new staff member. On the other side, companies can benefit from many skilled and experienced or key job seekers, regarding unemployment in the labour market. Employers are also in a better position to negotiate wages due to the higher labour supply. Within the main objective, the partial goals are related, that focus on gathering and determining the degree of the Covid-19 pandemic impact on the selected practices of human resources management (it was surveyed by managers of tourism companies operating in Slovakia on the Linkert scale, where 1 represents a very strong impact, 2 - strong impact, 3 - weak impact, 4- very weak impact, 5 - no impact) and subsequently finding out the rate of performance development in tourism companies, which ranged on an interval scale, where 1 means a very positive development, 2 - positive development, 3 - average development, 4 - negative development and 5 - very negative development. The online questionnaire was addressed to 274 managers who work in tourism companies in Slovakia. Out of the total number, were $64 \%$ women and $36 \%$ men. In one of the questionnaire questions, we found out the sector in which the managers work. The vast majority of respondents, work in the hospitality sector, specifically (41\% of managers), 15\% managers work in coffee and bars, $21 \%$ of managers work in a restaurant and the same number $12 \%$ of respondents work in travel agencies, $11 \%$ of managers work in pensions, and the least number of respondents work in spas, ski resorts, aquaparks (under 9\%). For the needs of the research, the following scientific research hypothesis were formulated:

H1: It is assumed that there is a statistically significant relationship between pandemic Covid-19 impact on the selected practices of human resources management and the degree of performance development in tourism companies in the Slovak Republic.

To test the above hypothesis, we used the statistical analysis, the aim of which is to know the regularity, context and developmental tendencies of mass phenomena. Out of the nonparametric tests, Chi-Square goodness of fit test was used, which tests the null statistical hypothesis, which states that the abundances in the individual categories are equal to the expected abundances. We can state that if the P-value is lower than the chosen level of significance (traditionally $5 \%=0.05$ ), the null hypothesis is rejected. At the same time, it can be stated, that the difference between the frequencies found in the sample and the expected frequencies is too large to be the result of random sampling alone, i.e. it is statistically significant. If the P-value is equal to or higher than the chosen level of significance, the null hypothesis cannot be rejected. It means that the difference between the frequencies found in the sample and the expected frequencies may be due to random selection, i.e. it is not statistically significant (Ostertagová, 2013). In the process of testing the hypothesis H1 were used non parametrical methods, therefore we proceed another testing Spearman's rank correlation coefficient $r S$, which measures the tightness of any statistical dependence that is monotonic. This is the coefficient that we can use to test the level of correlation intensity of two statistical forms, anywhere those statistical forms are measured on scales, and enables us the obtained results of testing to put in two orders. At the same time, the Kendall rank correlation coefficient was used, which measures the intensity of dependence between two ordered variables and provides the test of significance of the coefficient. Kendall's tau represents the difference between the probability that the values of two variables are in the same order against the probability that values are not in the same order (Ostertagová, 2013).

\section{RESULTS AND DISCUSSION}

The research we carried out in the tourism companies operating in the Slovak Republic, examines the relationship between the selected practices of human resources management and performance development during the pandemic COVID-19. Boselie (2014) state that there are five fundamental practices and so-called „best practices“, in human resources management: recruitment and selection of employees, employee training and development, evaluation and performance management, rewarding and participation of employees. Meantime, it points out that these practices in human resources management can be described as personal intervention or action contributed to the formation of legal relation ship in each company regardless of the field in which they operate. Also, they help companies to survive because they can positively 
affect financial results. The economic outcomes depend on organizational performance from the productivity, innovations and fluctuation point of view. For our research, we examined those practices of human resources management in which we can assume the considerable impact of Covid-19 on the management methods. The surveys in this particular field from the year 2020 points to the fact there were either none or only the occasional recruitment and selection in the companies provided. It is related to the effects of pandemic Covid-19 that redundancies occur rather than recruitment due to restricted movement. The other practices we can mention are training and development of employees, which often took place only in an online environment to which associated is the work from home. Therefore many virtual teams are nowadays being used.

The global crisis caused by the Covid-19 pandemic has recorded the dramatic increase of teamwork that reached perhaps the highest level we have ever seen in the last couple of years. The virtual teams act as a significant implication of global pandemic Covid-19 in human resources management. (Ichniowski et al.,1996; Truss et al., 2012) state that some of the practices of human resources management, e.g. individual or team promotion, are insufficient to accomplish high performance. Therefore, it is inevitable to use additional procedures to support employee's motivation and their relation to the organization. Training and education, communication mechanism, the participation of employees are also needed and necessary to use. In one of the significant part of the questionnaire, we asked respondents to rate the impact of pandemic Covid-19 on the management by our selected practices within the human resources management process in their companies.

There were the following practices:

- Recruitment and selection of employees $(R \& S)$,

- Training and development $(T \& D)$,

- Evaluation and management of employees' performance (E),

- Rewarding employees $(R)$,

- Employee participation $(P)$.

The results for the individual items with the characteristic of descriptive statistical methods can be visible in Table 1. For research purposes, it was necessary to find out to what extent the performance indicators have developed due to the pandemic Covid-19 impact on the companies. The primary task was to indicate the level of individual indicators of organizational performance in companies in which they worked during the last year and was significantly affected by the global pandemic crisis. The rate of performance development ranged on the interval scale, where 1 means very positive development, 2 - a positive development, 3 - average development, 4 - negative development and 5 - very negative development. Out of the performance indicators, were included in the questionnaire: return on assets, return of sales, work productivity and total inventory turnover. Durkáčová and Kalafusová (2012; Tomčíková, 2020), state that returns on assets refer to indicators of profitability and indicate the management capability to use the resources and property of the company to gain profit, i.e. profitability of business efforts. Return on assets expresses total profit/total assets. Among the profitability indicators, we also include the profitability of sales, which we can suggest as net profit/sales. Subsequently, we will approach the indicators of activity, namely the total inventory turnover. Activity indicators make it possible to quantify how efficient and effective a company uses its assets. Total inventory turnover expresses the following relationship: sales/average inventory. From the research results, we can state that not any of the analyzed tourism companies for the last year didn't develop very positive or negative at once total inventory turnover, labour productivity, return on sales and return on assets. The vast majority of companies show average or possibly negative, to very negative results of the above - mentioned indicators and their development. We conducted a similar survey in the year 2013, where we examined the impact of globalization on selected human resource management practices regarding organizational performance in multinational companies.

Table 1. Descriptive characteristics: the degree of the Covid-19 pandemic impact on the selected practices of human resources management (Source: developed by the authors)

\begin{tabular}{|l|c|c|c|c|c|c|c|}
\hline \multicolumn{1}{|c|}{ Practices of HRM } & N & Average & Median & SD & Dispersion & Min & Max \\
\hline Recruitment and selection (R\&S) & 274 & 1.65 & 2.00 & 0.65 & 0.43 & 1 & 3 \\
\hline Training and development (T\&D) & 274 & 1.75 & 2.00 & 0.71 & 0.51 & 1 & 3 \\
\hline Evaluation and management of employees' performance (E) & 274 & 1.72 & 2.00 & 0.63 & 0.40 & 1 & 3 \\
\hline Rewarding employees (R) & 274 & 1.62 & 2.00 & 0.70 & 0.46 & 1 & 3 \\
\hline Employees Participation (P) & 274 & 1.55 & 2.00 & 0.80 & 0.64 & 1 & 3 \\
\hline
\end{tabular}

In connection with the mapping of the relationship between the impact of the covid-19 pandemic on the selected practices of human resources management and performance measures of tourism companies in the Slovak Republic, a null and an alternative hypothesis $\mathrm{H} 1$ were formulated:

$$
\mathrm{H}_{0} \text { (null hypothesis): } \theta=\theta 0
$$

$H_{0}$ : It is assumed that there is not a statistically significant relationship between pandemic Covid-19 impact on the selected practices of human resources management and the degree of performance development in tourism companies in the Slovak Republic.

\section{H1 (alternative hypothesis): $\theta=\theta$}

$H_{1}$ : It is assumed that there is a statistically significant relationship between pandemic Covid-19 impact on the selected practices of human resources management and the degree of performance development in tourism companies in the Slovak Republic.

The results regarding the hypothesis testing are included in the following Table 2 and Table 3 . In the case of testing the relationships between the above variables, all tested relationships showed $\mathrm{p}<0.05$, so we reject the null hypothesis. We can state that the difference between the frequencies found in the sample and the expected frequencies is too large to be the result of random sampling alone, so it is statistically significant. 
The Impact of the Global Covid-19 Pandemic on the Selected Practices of Human Resources Management in the Relationship to the ...

Table 2. Results of testing H1: values of Chi-Square test (Source: developed by the authors)

\begin{tabular}{|c|c|c|c|c|c|c|c|c|}
\hline \multirow{2}{*}{$\begin{array}{c}\text { The degree of the Covid-19 } \\
\text { pandemic impact on the } \\
\text { practices of HRM }\end{array}$} & \multicolumn{7}{|c|}{ The rate of performance development (performance indicators) } \\
\cline { 2 - 9 } & Return on assets (PI1) & Return on sales (PI2) & Labor productivity (PI3) & Total stock turnover (PI4) \\
\cline { 2 - 9 } & Value & P-value & Value & P-value & Value & P-value & Value & P-value \\
\hline R\&S & 35.005 & 0.000 & 31.006 & 0.000 & 30.500 & 0.012 & 38.810 & 0.011 \\
\hline T\&D & 24.002 & 0.000 & 30.030 & 0.000 & 41.500 & 0.006 & 46.623 & 0.000 \\
\hline E & 57.700 & 0.000 & 53.300 & 0.000 & 90.004 & 0.007 & 52.270 & 0.000 \\
\hline R & 52.100 & 0.000 & 67.200 & 0.000 & 16.008 & 0.000 & 27.947 & 0.000 \\
\hline P & 100.12 & 0.000 & 19.009 & 0.000 & 33.020 & 0.000 & 46.002 & 0.000 \\
\hline
\end{tabular}

Table 3. Results of testing H1: values of correlation coefficients (Source: developed by the authors)

\begin{tabular}{|c|c|c|c|c|c|c|}
\hline \multirow{2}{*}{$\begin{array}{c}\text { Practices of } \\
\text { HR*performance } \\
\text { indicators }\end{array}$} & \multicolumn{9}{|c|}{ Values of correlation coefficients } \\
\cline { 2 - 7 } & Kendall's tau-b & \multicolumn{2}{|c|}{ Kendall's tau-c } & \multicolumn{2}{c|}{ Spearman Correlation } \\
\cline { 2 - 7 } & Value & P-value & Value & P-value & Value & P-value \\
\hline R\&S*PI1 & 0.401 & 0.000 & 0.458 & 0.011 & 0.439 & 0.011 \\
\hline R\&S*PI2 & 0.212 & 0.000 & 0.271 & 0.000 & 0.218 & 0.000 \\
\hline R\&S*PI3 & 0.300 & 0.011 & 0.325 & 0.000 & 0.352 & 0.000 \\
\hline R\&S*PI4 & 0.421 & 0.000 & 0.455 & 0.000 & 0.556 & 0.000 \\
\hline L\&D *PI1 & 0.400 & 0.000 & 0.365 & 0.012 & 0.556 & 0.000 \\
\hline L\&D *PI2 & 0.350 & 0.000 & 0.441 & 0.000 & 0.464 & 0.000 \\
\hline L\&D *PI3 & 0.402 & 0.000 & 0.344 & 0.000 & 0.405 & 0.000 \\
\hline L\&D *PI4 & 0.311 & 0.000 & 0.247 & 0.000 & 0.249 & 0.000 \\
\hline E*PI1 & 0.201 & 0.000 & 0.198 & 0.000 & 0.228 & 0.020 \\
\hline E*PI2 & 0.219 & 0.012 & 0.205 & 0.000 & 0.222 & 0.000 \\
\hline E*PI3 & 0.212 & 0.000 & 0.192 & 0.000 & 0.208 & 0.000 \\
\hline E*PI4 & 0.302 & 0.000 & 0.301 & 0.000 & 0.354 & 0.015 \\
\hline R*PI1 & 0.408 & 0.000 & 0.394 & 0.000 & 0.459 & 0.000 \\
\hline R*PI2 & 0.102 & 0.000 & 0.187 & 0.000 & 0.197 & 0.000 \\
\hline R*PI3 & 0.122 & 0.000 & 0.072 & 0.000 & 0.116 & 0.000 \\
\hline R*PI4 & 0.241 & 0.000 & 0.207 & 0.000 & 0.172 & 0.000 \\
\hline P*PI1 & 0.324 & 0.011 & 0.365 & 0.002 & 0.431 & 0.000 \\
\hline P*PI2 & 0.405 & 0.000 & 0.329 & 0.000 & 0.304 & 0.000 \\
\hline P*PI3 & 0.171 & 0.000 & 0.104 & 0.000 & 0.089 & 0.000 \\
\hline P*PI4 & 0.121 & 0.000 & 0.279 & 0.000 & 0.232 & 0.000 \\
\hline
\end{tabular}

As mentioned above, the correlation analyses with the use of two correlations coefficients were used. The Spearman coefficient takes values from the interval $\langle-1,1\rangle$ and is interpreted as a selection correlation coefficient. The values close to 0 indicate a weaker dependence of the variables, the value closer to 1 or -1 indicates the closer dependence. The extreme value 1 indicates a complete match of two orders, the extreme value of - 1 corresponds to exactly opposite orders. Positive values mean that the variables tend to change in the same direction, the negative values tend to change in different directions. It can be stated, that in all tested relations, the p-values of correlation coefficients are <0.05. In the case of the p-values of the Kendall rank correlation coefficient, which is a test of the coefficient significance, these values are lower than the selected significance level of 0.05 , i.e. the null hypothesis is rejected. It means that the difference between coefficients, as a result of the tested sample and zero, is too enormous to be a consequence of random selection, and it is therefore significant. We can state that there is a relationship between variables. Based on the above values, it is possible to verify and confirm hypothesis H1, that there is a statistically significant relationship between the Covid-19 pandemic impact on the selected practices of human resources management and the level of developmental performance in the tourism companies operating in the Slovak Republic in the last year.

\section{CONCLUSION}

Human resources management signify a critical function to secure effective company operating. It is the function that influences most of the company's significant resources, and it is usually the source of lasting competitive advantage in an unsustainable business environment. Many studies, including Huselid (1995), focused on the analyzes and they confirmed, that accurately implemented practices have significant effects on the companies' performance. The system of human resources management, according to Lado and Wilson (1994), is referred to as "organizational capabilities", and it is the dynamic process (recruitment and selection of employees, evaluation of their performance, training and promotion). It allows the company to acquire, develop and deploy its sources to enable the company to gain a competitive advantage.

In conclusion, we can state, that procedures and practices of human resources management, including the management itself, are affected by Covid-19 also the other sectors in a company. It is, therefore, to say that aim of our research was verified: to research and to analyze the relationship between the impact of the covid-19 pandemic on the selected practices of human resources management and performance measures of tourism companies in the Slovak Republic, in these uncertain and turbulent times. We can state, that the impact of the Covid-19 pandemic on the selected practices of human resources management effect the changes in organizational performance in tourism companies operating in Slovakia.

The hypothesis H1 which formulated for the needs of the research is confirm and we can state, that there is a statistically significant relationship between the Covid-19 pandemic impact on the selected practices of human resources management (recruitment and selection of employees, training and development, evaluation and management of employees' performance, rewarding employees, employee participation) and the level of developmental performance in the tourism 
companies operating in the Slovak Republic in the last year. The selected practices of human resources management are affected by Covid-19 pandemic, as the other sector of business management. Also, the impact of Covid-19 affects the changes in the performance development of tourism companies operating in the Slovak republic. The quality of human resources has become a precondition of success for each company. Success, in recent days, depends on the ability to maximize the potential and talents, not only for individuals but also for the teams.

\section{Acknowledgement}

This contribution presents some results from research projects GAMA/20/1 and GAMA/20/6.

\section{REFERENCES}

Andresen, M., \& Nowak, C.H. (2015). Human Resource Management Practices: Assessing Added Value (Management for Professionals), Springer International Publishing, Switzerland.

Baert, S., Lippens, L., Moens, E., Weytjens, J., \& Sterkens, L. (2020). The COVID-19 Crisis and Telework: A Research Survey on Experiences, Expectations and Hopes, IZA Institute of Labor Economics, Bonn, Germany.

Bakri, N.M., Jaafar, M., \& Mohamed, D. (2014). Perceptions of local communities on the economic impacts of tourism development in Langkawi, Malaysia. Conference: 4th International Conference on Tourism Research (4ICTR), Sabah, Malaysia. https://doi.org/10.1051/shsconf/20141201100

Baum, T. (2007). Human Resources in Tourism: Still Waiting for Change. Tourism Management, 50(6), 1383-1399. https://doi.org/10.1016/j.tourman.2007.04.005

Baum, T. (2015). Human resources in Tourism: Still waiting for change? - A 2015 Reprise. Tourism Management, 50, $204-212$. https://doi.org/10.1016/j.tourman.2015.02.001

Becker, B., \& Huselid, M.A. (1998). High performance work systems and firm performance: A synthesis of research and managerial applications. Research in Personnel and Human Resource Management, 16(1), 53-101.

Belzunegui-Eraso, A., \& Erro-Garcés, A. (2020). Teleworking in the Context of the Covid-19 Crisis. Sustainability Journal, 12(9), 3662, 118. https://doi.org/10.3390/su12093662

Boselie, P. (2014). Human resources management and performance: Adding value through people. In Strategic human resource management: A Balanced Approach (pp. 47-69). McGraw-Hill. New York, United States.

Carnevale, J.B., \& Hatak, I. (2020). Employee Adjustment and Well-Being in the Era of COVID-19: Implications for Human Resource Management. Journal of Business Research, 116, 183-187. https://doi.org/10.1016/i.jbusres.2020.05.037

Donthu, N., \& Gustafsson, A. (2020). Effects of COVID-19 on business and research. Journal of Business Research, 117, $284-289$. https://doi.org/10.1016/i.jbusres.2020.06.008

Durkáčová, M., \& Kalafusová, L. (2012). Tradičné a moderné prístupy k hodnoteniu výkonnosti podnikov ITraditional and modern approaches to evaluating the performance of companies]. In Trends and Innovative Approaches in Business Processes 2012. Th 15th International Scientific Conference, Košice, Slovakia (1-10), TUKE.

Gallo, P.J., Mihalčová, B., Gallo, P.Jr., Čabinová, V., \& Tomčíková, L'. (2019). Application of the Balanced Scorecard as a strategic management tool in practice: A case of Slovak tourism sector. GeoJournal of Tourism and Geosites, 24(1), 19-28. https://doi.org/10.30892/gtg.24102-339

Glaesser, D. (2006). Crisis Management in the Tourism Industry, Elsevier Science \& Technology Book, Oxford, United Kingdom.

Huselid, M.A. (1995). The Impact of Human Resource Management Practices on Turnover and Productivity. The Academy of Management Journal, 38(3), 635-872.

Ichniowski, C., Kochan, T., Levine, D., Olson, O., \& Strauss, G. (1996) What works at work. Industrial Relations, $35,299-333$. https://doi.org/10.1111/j.1468-232X.1996.tb00409.x

Királ'ová, A., \& Malec, L. (2016). Tourism development in the Slovak Republic after the global financial crisis. Marketing and management of innovations, 3, 208-220.

Lado, A.A., \& Wilson, M.C. (1994). Human Resource Systems and Sustained Competitive Advantage: A Competency-Based Perspective. Academy of Management Review, 19(4), 699-727. https://doi.org/10.2307/258742

Jiang, K., Lepak, D.P., Hu, J., \& Baer, J.C. (2012). How Does Human Resource Management Influence Organizational Outcomes? A Meta-Analytic Investigation of Mediating Mechanisms. The Academy of Management Journal, 55(6), 1264-1294. https://doi.org/10.5465/ami.2011.0088

Laws, E., Prideaux, B., \& Chon, K. (2006). Crisis Management in Tourism, Hong Kong Polytechnic University, Hong Kong, Republic of China.

Ostertagová, E. (2013). Aplikovaná štatistika [Applied statistics], Equilibria, Slovakia.

Matijová, M., Onuferová, E., Rigelský, M., \& Stanko, V. (2019). Impact of Selected Indicators of Tourism Capacity and Performance in the Context of the Unemployment Rate in Slovakia. Journal of tourism and services, 10(19), 1-23. https://doi.org/10.29036/jots.v10i19.95

Moyo, N. (2020). Antecedents of employee disengagement amid Covid-19 pandemic. Polish Journal of Management Studies, 22(1), 323334. https://doi.org/10.17512/pjms.2020.22.1.21

Truss, C., Mankin, D., \& Kelliher, C. (2012). Strategic Human Resource Management, Oxford University Press, United Kingdom.

Nickson, D. (2007). Human Resource Management for the Hospitality and Tourism Industries, Elsevier, New York, United States.

Pforr, C.H., \& Hosie, P. (2008). Crisis Management in Tourism. Journal of Travel \& Tourism Marketing, 23(2-4), 249-26. https://doi.org/10.1300/J073v23n02_19

Saad, S. (2013). Contemporary Challenges of Human Resource Planning in Tourism and Hospitality Organizations: A Conceptual Model. Journal of Human Resources in Hospitality \& Tourism, 12(4), 333-354. https://doi.org/10.1080/15332845.2013.790246

Tomčíková, L. (2020). Education and development of talented employees in relation to the performance of multinational organizations with regard to globalization. Journal of Applied Economic Sciences, 3(69), 570-578. https://doi.org/10.14505/jaes.v15.3(69).06

Turiecková, M. (2004). Řizení a rozvoj lidí ve firmách [Management and development of people in companies], Grada Publishing, Czechia.

Varma, A. (2008). Performance management systems: A global perspective, Routledge, United Kingdom.

Vösa, H. (2010). The Impact of Economic Crisis on HRM Practices in Estonia, Master's Thesis, Aalto University, Espoo, Finland.

Wagnerová, I. (2008). Hodnocení a ř́zení výkonnosti [Performance evaluation and management], Grada Publishing, Czechia.

Wagner, J. (2009). Měreni výkonnosti [Performance measurement], Grada Publishing, Czechia.

*** UNWTO. World Tourism Organization. (2018). Tourism Highlights 2018 Edition. https://www.e-unwto.org/doi/pdf/10.18111/9789284419876

*** WTTC. World Travel \& Tourism Council. (2019). Travel \& tourism economic impact 2019. https://wttc.org/Research/Economic-Impact 